\title{
Penentuan Jumlah Tenaga Kerja Berdasarkan Waktu Standar Dengan Metode Work Sampling Di Stasiun Repair Overhoul Gearbox (Studi Kasus: PT. IMECO Inter Sarana)
}

\author{
Dewi Diniaty $^{1}$, Irna Ariska ${ }^{2}$ \\ Jurusan Teknik Industri \\ Fakultas Sains dan Teknologi, UIN Sultan Syarif Kasim Riau \\ Jl. HR. Soebrantas No. 155 Simpang Baru, Panam, Pekanbaru, 28293 \\ Email: dewidiniaty@uin-suska.ac.id, iirnaariska@gmail.com
}

\begin{abstract}
ABSTRAK
PT. IMECO Inter Sarana merupakan perusahaan yang merakit Pumping Unit dan melakukan proses Repair Overhoul Gearbox. Gearbox adalah suatu alat yang mengubah daya dari motor yang berputar menjadi tenaga yang lebih besar. Namun pada prosesnya masih mengalami permasalahan dimana sebagian besar jumlah pesanan tidak dipenuhi perusahaan. Hal ini disebabkan karena adanya waktu menunggu atau antrian pada Gearbox dan keterbatasan jumlah operator dibagian Repair Overhoul Gearbox. Tujuan dari penelitian ini adalah melakukan pengukuran kerja untuk mengetahui berapa jumlah tenaga kerja standar pada stasiun tersebut untuk mengurangi waktu menunggu pada Gearbox dengan menggunakan metode work sampling. Dari hasil pengolahan data diperoleh bahwa waktu standar untuk operator I sebesar 1328 menitdan operator II sebesar 1310 menit, denganjumlah tenaga kerja yang dibutuhkan berdasarkan waktu standar untuk operator I sebesar 1,14 dan operator II sebesar 1,13. Dari hasil tersebut dapat disimpulkan bahwa faktor yang menyebabkan terjadinya antrian Gearbox bukan disebabkan oleh kekurangan operatortetapi ada faktor yang lebih mempengaruhi yaitu produktifitas yang belum maksimal.
\end{abstract}

Kata kunci : Work Sampling, Repair Overhoul Gearbox, Pumping Unit.

\section{ABSTRACT}

PT. IMECO Inter Sarana is a company that assembles Pumping Unit and conducts Repair Overhoul Gearbox process. A gearbox is a device that changes the power of a rotating motor into greater power. But in the process is still experiencing problems where most of the number of orders are not fulfilled by the company. This is due to the waiting time or queue on the Gearbox and the limited number of operators in the Repair Overhoul Gearbox section. The purpose of this research is to measure work to find out how many standard workforce on the station to reduce the wait time on the Gearbox by using the work sampling method. From the data processing, it was found that the standard time for operator I was 1328 minutes and operator II was 1310 minutes, with the amount of labor required based on standard time for operator I of 1.14 and operator II of 1.13. From these results can be concluded that the factors that cause the occurrence of Gearbox queue is not caused by the lack of operators but there are factors that affect the productivity is not maximal.

Keywords: Work Sampling, Repair Overhoul Gearbox, Pumping Unit.

\section{Pendahuluan}

Perekonomian bangsa Indonesia sekarang ini sedang mengalami pasang surut. Hal ini akan berdampak pada terhambatnya perkembangan industri ditanah air. Perusahaan harus menanggung biaya produksi untuk menghasilkan produk yang berkualitas agar diminati konsumen. Untuk mempertahankan dari krisis ini, perusahaan melakukan pemutusan hubungan kerja kepada beberapa karyawannya. 
Perusahaan dalam menjalankan kegiatan produksinya, harus selalu berusaha untuk memanfaatkan sebaik mungkin sumber daya yang dimiliki karyawan produksi sebagai komponen penting dalam kegiatan produksi harus ditingkatkan. Produktivitas tenaga kerja sesuai dengan skill (keterampilan), pengetahuan dan pengalaman yang dimiliki. Peranan karyawan produksi pada stasiun kerja perlu mendapat perhatian dari pihak manajemen perusahaan.

Tenaga kerja merupakan faktor yang penting dalam menjamin kelancaran proses produksi. Ketersediaan tenaga kerja dengan tingkat keterampilan yang memadai dan dengan jumlah yang tepat selalu menjadi tujuan dari pelaksanaan dari produksi itu sendiri, meskipun tidak melupakan faktor penting lainnya yang berpengaruh dalam proses produksi seperti mesin, peralatan dan lain sebagainya. (Nurjannah, 2009).

PT. IMECO Inter Sarana adalah perusahaan manufacture dan maintenanceyang memproduksi Pumping Unit. Bidang usaha ini mempunyai pesaing yang cukup banyak, sehingga untuk meraih pasar diperlukan adanya produk yang berkualitas dan memberikan pelayanan yang cepat sesuai dengan waktu yang diperlukan. Tenaga kerja khususnya stasiun repair Overhoul Gearbox mengalami waktu menunggu atau antrian Gearbox sehingga tidak bisa memenuhi target produksi. Untuk memperbaiki beban kerja maka diusulkan bagaimana dilakukan pengukuran kerja dengan metode work sampling yang bertujuan untuk menentukan waktu standar kerja sehingga diketahui jumlah tenaga kerja yang diperlukan dalam proses repair Overhoul Gearbox dan mengetahui tingkat produktivitas tenaga kerja.

\section{Gearbox}

Gearbox merupakan suatu alat khusus yang diperlukan untuk menyesuaikan daya atau torsi (momen atau daya) dari motor yang berputar, dangearbox juga adalah alat pengubah daya dari motor yang berputar menjadi tenaga yang lebih besar. Gearbox atau transmisi adalah salah satu komponen utama motor yang disebut sebagai sistem pemindah tenaga, transmisi berfungsi untuk memindahkan dan mengubah tenaga dari motor yang berputar, yang digunakan untuk memutar spindel mesin maupun melakukan gerakanfeeding. Transmisi juga berfungsi untuk mengatur kecepatan gerak dan torsi serta berbalik putaran, sehingga dapat bergerak maju dan mundur. Transmisi manual atau lebih dikenal dengan sebutan gearbox, mempunyai beberapa fungsi antara lain (Rachmawan, 2012):

1. Merubah momen puntir yang akan diteruskan ke spindel mesin.
2. Menyediakan rasio gigi yang sesuai dengan beban mesin.

3. Menghasilkan putaran mesin tanpa selip

\section{Pengukuran Kerja dengan MetodeWork Sampling}

Sampling kerja atau work sampling adalah suatu teknik untuk mengadakan sejumlah besar pengamatan terhadap aktivitas kerja dari mesin, proses atau pekerja atau operator. Pengukuran kerja dengan metode sampling kerja ini sama halnya dengan pengukuran kerja dalam jam henti (stop watch time study) diklasifikasikan sebagai pengukuran kerja secara langsung karena pelaksanaan kegiatan pengukuran harus secara langsung ditempat kerja yang diteliti. Bedanya dengan cara jam henti adalah bahwa pada cara sampling pekerjaan pengamat tidak terus menerus berada di tempat pekerjaan melainkan mengamati hanya pada waktu-waktu yng telah ditentukan secara acak (Wignjosoebroto, 2006).Metode sampling kerja ini telah terbukti sangat efektif dan efisien untuk digunakan dalam mengumpulkan informasi mengenai kerja dari mesin atau operator. Dikatakan efektif karena denagan cepat dan mudah cara ini dapat dipakai untuk mengetahui tingkat pendayagunaan waktu tenaga kerja, mesin, proses, penentuan waktu longgar (allowance time) yang tersedia untuk satu pekerjaan, juga untuk penentuan waktu baku atau waktu standar untuk suatu proses produksi. Dibandingkan dengan metode kerja yang lain, metode sampling kerja lebih efisien karena informasi yang dikehendaki akan didapatkan dalam waktu relatif lebih singkat dan dengan biaya yang tidak terlalu besar(Nurjannah, 2009).

\section{Pelaksanaan Work Sampling}

Sebelum melakukan sampling terlebih dahulu kita harus melakukan langkah-langkah persiapan awal yang terdiri atas pencatatan segala informasi dari semua fasilitas yang ingin diamati serta merencanakan jadwal waktu pengamatan berdasarkan prinsip randomisasi. Setelah itu barulah kita melakukan sampling pekerjaan yang terdiri dari tiga langkah yaitu (Nurjannah, 2009):
a. Melakukan sampling pendahuluan
b. Menguji keseragaman data
c. Menghitung jumlah kunjungan yang diperlukan

\section{Menentukan Jadwal Waktu Pengamatan Secara Acak \\ Pada langkah ini dilakukan sejumlah pengamatan terhadap aktivitas kerja untuk selang waktu yang diambil secara acak. Untuk ini biasanya satu hari kerja dibagi kedalam satuan- satuan waktu yang besarnya ditentukan oleh}


pengukur. Biasanya panjang satu satuan waktu tidak terlalu panjang. Berdasarkan satu satuan waktu inilah saat-saat kunjungan ditentukan. Misalnya satu satuan waktu panjangnya 5 menit, jadi satu hari kerja (7 jam) mempunyai 84 satuan waktu. Ini berarti jumlah kunjungan perhari tidak lebih dari 84 kali. Jika dalam satu hari dilakukan 36 kali kunjungan maka dengan bantuan tabel bilangan acak ditentukan saat-saat kunjungan tersebut (Nurjannah, 2009).

\section{Pengujian Kecukupan Data}

Pengujian kecukupan data adalah suatu pengujian yang berguna untuk memastikan bahwa data yang digunakan cukup untuk digunakan sebagai bahan penelitian. Jumlah pengamatan untuk tingkat ketelitian $5 \%$ dan tingkat keyakinan $95 \%$ diketahui melalui rumus (Sutalaksana, 1979):

$\mathrm{N}^{\prime}=\frac{1600(1-\mathrm{P})}{\mathrm{P}}$

\section{Pengujian Keseragaman Data}

Pengujian keseragaman data adalah suatu pengujian yang berguna untuk memastikan bahwa data yang dikumpulkan berasal dari suatu sistem yang sama. Batas-batas kontrol dengan menggunakan rumus uji keseragaman data untuk tingkat kepercayaan $95 \%$ dan tingkat ketelitian 5 $\%$ maka (Nurjannah, 2009):

$\mathrm{BKA}=\overline{\mathrm{p}}+2 \sqrt{\frac{\overline{\mathrm{p}}(1-\overline{\mathrm{p}})}{\overline{\mathrm{n}}}}$

1)

$$
\mathrm{BKB}=\overline{\mathrm{p}}-2 \sqrt{\frac{\overline{\mathrm{p}}(1-\overline{\mathrm{p}})}{\overline{\mathrm{n}}}}
$$

\section{Aplikasi Sampling Kerja Untuk Penetapan Waktu Standar \\ Seperti halnya dalam stop watch time study} maka disini juga harus diestimasikan terlebih dahulu rating factor dari tenaga kerja yang diukur dan waktu longgar (allowance) yang ada. Sehingga waktu baku penyelesaian suatu produk dapat dinyatakan dalam rumusberikut (Nurjannah, 2009):

$$
\text { Waktu Standar }=\frac{\text { TT x WT } \times \mathrm{RF}}{\sum \mathrm{Yi}} \times \frac{100 \%}{100 \%-A l l}
$$

\section{Perhitungan Jumlah Kebutuhan Tenaga Kerja Standar Berdasarkan Waktu Standar}

Setelah waktu baku atau waktu standartelah diketahui serta data sudah seragam dan sudah mencukupi maka dilanjutkan denganpenghitungan jam kerja produktif dan waktu total pengerjaan produk, untuk menetukan jumlah kebutuhan tenaga kerja standar (Nurjannah, 2009):
1. Menghitung jam kerja produktif

$\mathrm{JKP}=$ Total waktu kerja $\mathrm{x}$ Jumlah hari pengamatan (4)

$\mathrm{JKP}=$ Jumlah jam kerja produktif

2. Menghitung waktu total pengerjaan seluruh produk

$\mathrm{Wt}=\mathrm{WsxYi}(5)$

3. Menghitung kebutuhan tenaga kerja standar $\mathrm{JTK}=\frac{\mathrm{Wt}}{\mathrm{JKP}}(6)$

\section{Metode Penelitian}

Data yang digunakan adalah jumlah data produktivitas tenaga kerja saat melakukan repair Overhoul Gearbox.Langkah-langkah dalam pengolahan data adalah sebagai berikut:

1. Perhitungan Produktivitas Operator

Perhitungan produktivitas operator dilakukan untuk mengetahui persentase produktivitas operator.

2. Uji Keseragaman Data

Uji keseragaman data dilakukan untuk mengetahui apakah data yang telah dikumpulan telah seragam atau belum yang ditandai dengan tidak adanya data yang out of control. Uji keseragaman data dilakukan dengan tingkat kepercayaan $95 \%$ dan tingkat ketelitian $5 \%$.

3. Uji Kecukupan Data

Uji Kecukupan data dilakukan untuk setiap hari pengamatan dan uji kecukupan data untuk setiap operator untuk mengetahui apakah pengamatan yang dilakukan telah mencukupi atau tidak. Dimana jika pengamatan yang seharusnya dilakukan (N') lebih kecil dari jumlah pengamatan yang telah dilakukan (N) $\left(\mathrm{N}^{\prime} \leq \mathrm{N}\right)$ maka data telah mencukupi dan pengamatan dihentikan. Uji kecukupan data dilakukan dengan tingkat kepercayaan $95 \%$ dan tingkat ketelitian $5 \%$.

4. Perhitungan Waktu Standar

Perhitungan waktu standar dilakukan untuk mengetahui berapa waktu standar yang diperlukan operator dalam melakukan proses pengepakan yang disesuaikan dengan total waktu pengamatan, rating factor dan allowance.

5. Perhitungan Jumlah Tenaga Kerja Standar Perhitungan jumlah tenaga kerja standar dilakukan untuk mengetahui jumlah tenaga kerja optimum yang seharusnya dipekerjakan oleh perusahaan. Untuk menghitung jumlah kebutuhan tenaga kerja standar maka dilakukan perhitungan waktu total dalam 
mengerjakan produk dan jumlah jam kerja produktif (JKP) yang disesuaikan dengan jumlah hari kerja.

\section{Hasil dan Pembahasan}

\section{Produktifitas Operator}

Dari tabel hasil pengamatan sampling kerja maka didapatkan persentase produktifitas masingmasing

Tabel 1. Persentase Produktifitas

\begin{tabular}{|c|c|c|c|c|}
\hline Hari & Produktif & $\begin{array}{c}\text { Non } \\
\text { Produktif }\end{array}$ & Jumlah & \% P \\
\hline $\mathbf{1}$ & 52 & 4 & 56 & $\begin{array}{c}0,928 \\
5\end{array}$ \\
\hline $\mathbf{2}$ & 50 & 4 & 54 & $\begin{array}{c}0,925 \\
9\end{array}$ \\
\hline $\mathbf{3}$ & 52 & 4 & 56 & $\begin{array}{c}0,928 \\
5\end{array}$ \\
\hline \multicolumn{4}{|c|}{ Rata- Rata } & $\begin{array}{c}\mathbf{0 9 9 2 7} \\
\mathbf{7}\end{array}$ \\
\hline
\end{tabular}
kecukupan:

Berdasarkan tabel diatas didapatkan uji

$N^{\prime}=\frac{1600(1-\mathrm{P})}{\mathrm{P}}=\frac{1600(1-0,9277)}{0,9277}=\frac{115,68}{0,9277}=124$

Karena $N^{\prime}<\mathrm{N}$, maka data yang diukur telah dinyatakan cukup dengan data yang dibutuhkan sebanyak 124 data dan data pengamatan adalah sebnyak 166 data, sehingga tidak perlu lagi dilakukan pengambilan data.

\section{Uji Keseragaman Data}

$$
\begin{aligned}
\mathrm{BKA}=0,9277+2 & \sqrt{\frac{0,9277(1-0,9277)}{55}} \\
& =0,9975 \\
\mathrm{BKB}=0,9277-2 \sqrt{\frac{0,9277(1-0,9277)}{55}} & =0,8579
\end{aligned}
$$

\section{Uji Keseragaman Produktifitas Operator}

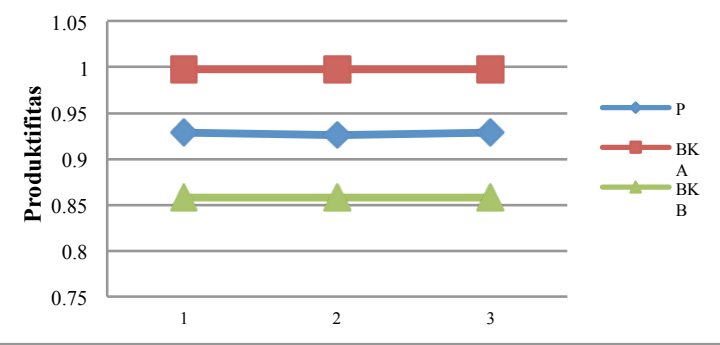

Gambar 1. Uji Keseragaman Produktifitas Operator
Dari perhitungan batas kontrol yang diperoleh dari gambar diatas diketahui bahwa data berada dalam batas kontrol sehingga dapat disimpulkan bahwa data seragam.

\section{Waktu Standar}

Perhitungan waktu standar dilakukan untuk mengetahui seberapa besar waktu yang dibutuhkan pekerja dalam melakukan Repair Overhoul Gearbox berdasarkan rating factor dan allowance yang dimiliki oleh operator tersebut.

Waktu Standar $=\frac{\text { TT } \times \text { WT } \times \mathrm{RF}}{\sum \mathrm{Yi}} \times \frac{100 \%}{100 \%-A l l}$

$$
\begin{aligned}
& =\frac{(3 \times 10 \times 60) \times(0,9277) \times(1+0,17)}{2} \times \frac{100}{100-27} \\
& =976,86 \times 1,36 \\
& \quad=1328 \text { menit }
\end{aligned}
$$

\section{Jumlah Kebutuhan Tenaga Kerja}

$\mathrm{Wt}=\mathrm{Ws} \times \mathrm{Yi}$

$=1328$ menit $\times 11,08$

$=14714,24$ menit

$\mathrm{JKP}=($ Total waktu kerja periode $\mathrm{x} 60$ menit $)$

$=(21,33 \times 10 \times 60$ menit $)$

$=12798$ menit

$\mathrm{JTK}=\frac{\mathrm{Wt}}{\mathrm{JKP}}$

$=\frac{14714,24}{12798}$

$=1,14$ orang

\section{Analisa Work Sampling}

\section{Uji Kecukupan Data}

Pada hari pertama dan kedua data yang didapatkan adalah data produktif, sehingga setelah dilakukan perhitungan uji kecukupan data, data dinyatakan belum mencukupi dan perlu melakukan pengamatan lagi. Dilanjutkan pada hari ketiga data yang didapatkan sebanyak 56 data dan 52 dari data tersebut adalah data produktif, data telah dinyatakan cukup karena data yang dibutuhkan sebanyak 124 data dan data pengamatan adalah sebanyak 166 data, sehingga $N^{\prime}<N$.

2. Uji Keseragaman Data

Berdasarkan perhitungan uji keseragaman data operator didapat batas kontrol atas (BKA) sebesar 0,99 batas kontrol bawah (BKB) sebesar 0,85 dan persentase produktif dari perhitungan hari pertama 0,9285 , hari kedua 0,9259 dan hari ketiga 0, 9285. 
Sehingga data dinyatakan berada di dalam batas kontrol dan dinyatakan data seragam.

3. Faktor Penyesuaian (Rating Factor) Berdasarkan tabel-tabel faktor penyesuaian didapatkan nilai faktor penyesuaian untuk operator tersebut didapatkan adalah sebesar 1,17 yang berarti $\mathrm{P}>1$ maka dapat diambil kesimpulan bahwa operator bekerja cepat.

4. Faktor Kelonngaran

Berdasarkan perhitungan faktor kelonggaran didapatkan nilai kelonggarannya untuk operator adalah $27 \%$. Berdasarkan ketentuan untuk faktor kelonggaran, dimana jika nilai kelonggaran $=1$ adalah kelonggaran yang wajar, nilai kelonggaran $>1$ adalah diatas kewajaran, dan nilai kelonggaran $<1$ adalah di bawah kewajaran maka nilai kelonggaran $27 \% \quad(0,27) \quad$ yang didapatkan dari perhitunganadalah berada di bawah kewajaran.

\section{Waktu Standar}

Waktu baku atau waktu standar untuk operator yang didapat pada Repair Overhoul Gearbox adalah sebesar 1328menit.Diperoleh waktu standar yang berbeda-beda pada operator dikarenakan ranting factor maupun kelonggaran yang dimiliki setiap operator berbeda-beda.Sehingga waktu standar yang sudah diperoleh dapat diketahui jumlah tenaga kerja yang seharusnya dipekerjakan untuk menyelesaikan proses Repair Overhoul Gearbox.

6. Jumlah Tenaga Kerja Standar

Berdasarkan perhitungan didapatkan waktu total produktifnya 14714,24 menit dan jam kerja produktif 12798 menit, sehingga didapatkan hasil jumlah tenaga kerja sebesar 1,14. Setelah dilakukan pengolahan data didapatkan hasil yang tidak terlalu significant, faktor yang menyebabkan terjadinya antrian bahan baku pada stasiun Repair Overhoul Gearbox bukan karena kekurangan operator pada stasiun tersebut, tapi ada faktor yang lebih mempengaruhi yaitu produktifitas operator pada stasiun Repair Overhoul Gearbox yang belum maksimal. Jadi untuk mengurangi antrian Gearbox pada stasiun tersebut operator harus meningkatkan produktifitas kerjanya dengan cara mengurangi kegiatan-kegitan non produktif.

\section{Daftar Pustaka}

Anggraeni, Linanda Eka dan Rony Prabowo. Analisis Beban Kerja untuk Menentukan Jumlah Karyawan Optimal (Studi Kasus: PT. Sanjayatama Lestari Sirabaya). Institut Teknologi Adhi Tama Surabaya. Surabaya. 2015.

Izzhati, Dwi Nurul. Implementasi Metode Work Sampling Guna Mengukur Produktivitas Tenaga Kerja di CV. Sinar Krom Semarang, Universitas Dian Nuswantoro. Semarang. 2012.

Jono. Pengukuran Beban Kerja Tenaga Kerja dengan Menggunakan Metode Work Sampling (Studi Kasus di PT. XY Yogyakarta). Universitas Widya Mataram. Yogyakarta. 2015.

Kiayi, Syamsir Djafar. Analisis Perancangan Waktu Standar dengan Menggunakan Metode Work Sampling (Studi Kasus di Kawasan Industri Agro Terpadu Kab. Bone Bolango).Fakultas Teknik Universitas Negeri Gorontalo, Gorontalo. 2010.

Nurjannah, Piqih. Penentuan Jumlah Tenaga Kerja Berdasarkan Waktu Standar dengan Metode Work Sampling di Bagian Packing pada PT. Sinar Oleochemical International. Universitas Sumatera Utara, Medan. 2009.

Rachmawan, Sendhi. Analisis Penyebab Kegagalan Potensial pada Proses Produksi dengan Menggunakan Metode Mafta (Studi Kasus pada Perusahaan Pembuat Pumping Unit). Universitas Indonesia. Jakarta. 2012.

Rinawati, Dyah Ika Dkk. Penentuan Waktu Standar dan Jumlah Tenaga Kerja Optimal pada Produksi Batik Cap (Studi Kasus: Ikm Batik Saud Effendy, Laweyan). Universitas Diponegoro. Semarang. 2012.

Sukma, Novita dkk. Analisis Pengukuran Waktu Kerja dengan Metode Pengukuran Kerja Secara Langsung pada Bagian Pengemasan PT. Japfa Comfeed Indonesia Tbk. Jurusan Teknologi Industri Pertanian-Fakultas Teknologi PertanianUniversitas Brawijaya. Malang. 2013.

Sutalaksana, Iftikar Z dkk. Teknik Tata Cara Kerja. Jurusan Teknik Industri Institut Teknologi Bandung, Bandung. 1979.

Wignjosoebroto, Sritomo. Studi Gerak dan Waktu. Guna Widya, Jakarta. 2006.

Wibowo, Koento Danny dan Andri Prasetya. Analisa Produktifitas Pekerja dengan 
Metode Work Saimpling (Studi Kasus

pada Proyek $X$ dan Y). Teknik Sipil

Universitas Kristen Petra, Surabaya. 2009. 